\title{
Law Enforcement of Land Transfer from Agricultural Land to Housing in Indonesia
}

\author{
Yeni Widowaty ${ }^{1, *}$, Triyono ${ }^{2}$, Dimas Amanda Wahid ${ }^{3}$ \\ ${ }^{1}$ Master of Law, Universitas Muhammadiyah Yogyakarta, Brawijaya Street Kasihan Bantul \\ Yogyakarta, Indonesia \\ ${ }^{2}$ Agribusiness Department, Universitas Muhammadiyah Yogyakarta, Brawijaya Street Kasihan \\ Bantul Yogyakarta, Indonesia \\ ${ }^{3}$ Student Master of Law, Universitas Muhammadiyah Yogyakarta
}

\begin{abstract}
Along with the rate of conversion of agricultural land to nonagricultural land, agricultural resources that need to get priority are those for food. The formulation of the problem is: 1) is the implementation of the conversion of agricultural land for housing in accordance with applicable regulations? 2) How is the law enforcement against the violation of the conversion of agricultural land use that is used for housing? 3) What is the ideal concept of law enforcement so that agricultural land conversion does not occur? The type of research used is socio-legal research, which includes primary data and secondary data. The results showed that the regulations regarding the conversion of agricultural land in principle had been implemented in accordance with the applicable regulations, especially regarding the requirements of the conversion of agricultural land. However, there are still violations of the construction of buildings carried out illegally. Law enforcement against violations of land-use change has not been carried out to the fullest, administratively there have been actions taken, but criminals have never been carried out. In the future, law enforcement must consider the reasons for the conversion of agricultural land, whether for public interest or for business ventures.
\end{abstract}

\section{Introduction}

Land is the basic resource for human society. Along with population growth, urbanization and industrialization, the rapid speed of economic development puts pressure on a country's small natural resource base. This creates a significant challenge for researchers and policymakers to strike a balance in the use of natural uses, considering the need for sustainable growth and food and livelihood protection for their conservation. Land has often been the subject of controversy about its successful usage as a fundamental natural resource [1].

Land issues, especially those related to the transfer of functions, have been proven to have a very detrimental impact on the community as has happened in the conversion of agricultural land for housing and other uses.

\footnotetext{
* Corresponding author: yeniwidowaty@umy.ac.id
} 
The increasing number of functions occurred not only due to ineffective laws and regulations but also because the government is less strict in enforcing the regulations in granting permits for the conversion of agricultural land into non-agricultural land. This can be caused by the factor that farmers who are no longer able to work on agricultural land because of the scarce or expensive means of production, such as fertilizer, seeds, and the lack of agricultural labor.

The total area of agricultural land in the city of Yogyakarta in 2010 was 85 ha, in 2015 there was only 62 ha, Sleman regency had 22,619 ha of agricultural land in 2010, in 2015 only 21,907 ha. Bantul Regency from 15,465 agricultural land areas in 2010 also dropped to 15,225 in 2015 [2]. Almost all regions experienced a decline in agricultural land area. At this time, the possibility of agricultural land is reduced more because in 2017 stood a number of hotels and also housing.

The issue of providing agricultural land for food production is currently experiencing significant problems and challenges. The threat of conversion of agricultural land to nonagricultural land has the potential to threaten the sustainability of regional food security in supporting national food security. Yogyakarta Special Region is the first region in Indonesia to have a Regional Regulation on the Protection of Sustainable Agricultural Land. However, socialization to the public about the Regional Regulation is still lacking. It is feared, the lack of socialization will harm agricultural landowners who will become sustainable agricultural land [3].)

Various policies related to the problem of controlling the conversion of agricultural land, mainly rice fields have been made. However, its implementation is less effective because it is not supported by adequate data and proactive attitudes from stakeholders. Besides, the lack of law enforcement against the perpetrators also triggers the continuity of agricultural land conversions. This raises the question of whether of the conversion of agricultural land for housing in accordance with applicable regulations. In addition, how is the law enforcement against the violation of the use of Sustainable Food Agriculture Land that is used for housing the Special Region of Yogyakarta?

Lawrance M. Friedman in [4] argued that effective and successful law enforcement depends on three elements of the legal system, structures of law, the substance of the law, and legal culture. The legal structure regarding law enforcement officers, the legal substance covering the legislation, and legal culture are living laws embraced in the society.

Research problems

a. Is the implementation of the conversion of agricultural land for housing in accordance with applicable regulations?

b. How is the law enforcement against the violation of the use of Sustainable Food Agriculture Land that is used for housing the Special Region of Yogyakarta?

c. What is the ideal concept of law enforcement so that agricultural land conversion does not occur?

\section{Literature Review}

\subsection{Law Enforcement}

Law enforcement is an essential aspect in society, and state life, stability, and social control start from here. A law - however good - will be of no use if it is unable to create order and become social control. Since the monarchy era, social control through law enforcement in the judiciary has become a serious thing [5]. 
Law Enforcement is an effort to apply the law in concrete situations both through the judicial process and outside the court so that the level of obedience to the law can be determined. It is vital to realize together that law enforcement is currently experiencing a crisis. The crisis was mainly caused by differences in the paradigm of law enforcement officers who always prioritized legal certainty by ignoring the aspects of justice and expediency. This means that law enforcement officials, especially those who deal directly with the court, pay more attention to regulations and procedures so that justice becomes marginalized [6]. Law enforcement is unique because police officers see their jobs as a way of defending and helping the community, requiring respect for others' dignity and individuality [7].

Law enforcement is a process in realizing legal desires into reality. The so-called legal will here is the mind of the legislature, which is formulated in the rule of law. The formulation of the thoughts of lawmakers, as stipulated in the law, will also determine how law enforcement is carried out [8]. Lawrence M. Friedman supported [8] that to determine the law enforcement process is by several factors, the substance, structure, and cultural components. Some of these components include the scope of operation of law as a system.

Cultural or legal culture includes the ideals of community law and the professional ethics of law enforcement officers. Public order can be realized if there is legal authority. The authority of the law is also greatly influenced by the authority of the law enforcement apparatus. In contrast, the authority of the law enforcement apparatus is strongly influenced by whether or not a sense of justice is fulfilled. The creation of legal authority is strongly influenced by legal awareness. Legal awareness itself is strongly influenced by justice[6].

In enforcing the law, three elements must be considered by Legal Certainty, benefit, and Justice [9]. The law must be implemented and enforced so that it becomes everyone's hope that the enactment of the law is an actual or concrete event. So that in the level of implementation, the applicable law may not deviate. Benefits are something that is expected by the community in law enforcement and enforcement so that the existence of legal benefits is no longer found unrest in society at the level of law enforcement. Meanwhile, justice absolutely must be considered in realizing law enforcement. The law must be fair and binding on everyone and generalizing. Thus, justice can be realized.

The efficiency of law enforcement extends only to small groups committing minor crimes. At the same time, the perpetrators of major crimes such as corruption, collusion, and nepotism are very difficult to touch. It takes courage for the community, especially law enforcement officials, to make a breakthrough in solving existing cases [10].

In essence, law enforcement requires the primacy of substantial importance, namely justice. Law enforcement is a series of processes to describe values, ideas, ideas that are quite abstract as the objectives of the law. The purpose of the law is the essence of law enforcement, in addition to upholding justice. It also contains moral values and truth[8].

Implementation of law enforcement from Joseph Goldstein proposes that the application or enforcement of criminal law can be divided into (1) Total Enforcement, (2) Full Enforcement, and (3) Actual Enforcement[11].

Law enforcement, especially in the case of the environment, is closely related to how the efforts of the state apparatus in overcoming it and how citizens' compliance with the rules that have been applied. This is why the law is said not to be able to work in a vacuum, and the law will always interact to adjust based on the conditions that occur around it [12]. It includes three instruments of instruments in administrative matters, instruments in criminal matters, and instruments in civil matters. If, in the case of the environment, it has caused pollution and/or damage, then comprehensive measures are needed as a means of maximum empowerment [13].

Regarding the three instruments that are stages or references in environmental cases can be explained as follows: 


\subsubsection{Administrative Instruments}

The instrument of law enforcement in administrative terms is an instrument more directed towards preventive measures, such as those concerning the ecosystem of an environment, environmental permit requirements, environmental quality standards, Environmental Impact Analysis, and environmental management and protection plans. Administrative facilities can be carried out by efforts to provide facilities for environmental management, especially in the field of financing or finance, import duties on pollution prevention tools, and bank credit for environmental management.

These administrative sanctions play an important role in the monitoring of illegal environmental practices, with many types of administrative sanctions: written notice, coercion by the government, suspension of the environmental permit and revocation of the environmental permit.

The purpose of imposing administrative sanctions. In accordance with Article 2 of the Minister of Environment Regulation No. 2 of 2013, the purpose of imposing administrative sanctions is:

1. Protect the environment from pollution and/or damage resulting from a business and/or activity;

2. Tackling environmental pollution and/or damage;

3. Restoring the quality of the environment due to environmental pollution and/or damage;

4. Give a deterrent effect for those in charge of businesses and/or activities that violate the laws and regulations in the field of environmental protection and management and the provisions in the Environmental Permit

This is based on the application of administrative sanctions, which include the legality of authority, proper procedures, the accuracy of the application of sanctions, the certainty of juridical disability, and refers to the principles of welfare and sustainability.

\subsubsection{Criminal Instruments}

Environmental offenses in Environmental Laws Number 32 of 2009 contain two types of offenses of material offenses and formal offenses. The material offense is an act that is prohibited by law because the act has resulted in something from the act. Whereas for the formal offense is an act that is prohibited by law, but there is no effect of the act. Material offenses contained in the Environmental Laws are found in Article 98, Article 99, Article 112, while formal offenses are listed in Article 100 to Article 111 and Article 113 to Article 115. Actually, activities relating to the implementation of environmental criminal proceedings in Indonesia still apply to Law No. 8 of 1981 on the Law of Criminal Procedure (Criminal Code).

\subsubsection{Civil Instruments}

Law enforcement in environmental cases can be reached through two ways by litigation and non-litigation

\section{Deliberation}

Settlement of disputes or environmental cases can be done by deliberation, mediation (by using the services of mediators) and arbitration (by using the services of an arbitrator) to reach an agreement on the settlement of:

a. The form and amount of compensation that must be given to victims and the environment ecosystem. 
b. Recovery actions due to the destruction or pollution in the form of revegetation, reforestation, and reclamation.

c. Certain actions to ensure there is no action to repeat the pollution or damage to the environment.

d. Certain actions to prevent negative impacts on the environment from environmental damage or pollution.

The settlement of environmental disputes is carried out voluntarily by both parties in the absence of intimidation or lure from other parties, in accordance with Article 84 paragraph (2) of the Environmental Laws. Dispute resolution outside the court line does not apply to environmental crimes. This is in accordance with Article 85 paragraph (2) of the Environmental Laws

\section{Litigation}

Settlement of environmental case disputes through the court is pursued if, through the outside court in the form of deliberation, mediation and arbitration do not reach an agreement, or one of the parties continues to try to take the court to obtain true justice, this is in accordance with Article 84 paragraph (3) of the Environmental Laws.

As for the principles that need to be made a reference and need to be considered by the panel of judges to hear environmental cases, including:

a. Require compensation for the perpetrators/corporations whose actions have caused pollution or damage to the environment.

b. Any person who seeks to move, change the essence and mode of business/activity of a business entity in violation of the law shall not relinquish the legal obligations of the business entity. [14].

c. Determination of forced money against delays in implementing court decisions.

d. The sum of forced cash complies with constitutional regulations.

\subsection{The Definition of Agricultural Land}

A broad understanding of the land is a surface region of the earth's land surface whose characteristics involve all recognition from the biosphere, climate, soil, geology, hydrology, and population of plants and animals, both of a reasonably stable and predictable nature, and the effects of human activities in the past and present, to the degree that such identifying marks influence the myrtle. [15].

The land has an important meaning for stakeholders who use it. It functions as a place to live and a source of livelihood. For residents who have a farming profession, the land is a source of food production and survival. For the private sector, the land is an asset to accumulate capital. For the government, the land is the sovereignty of a country, and for the welfare of its people. As a result, there are many interrelated interests in land use due to the overlapping interests between farmers, the private sector, and the government in utilizing land [16].

By definition, agricultural land is land that is or may be used for agriculture and crop farming. The main focus of agriculture is soil cultivation for the annual or perennial production of grains, vegetables and fruits. It includes soil preparation and proper maintenance, sowing and planting, the selection of seeds and crop varieties, pest and disease control, and harvesting. Agriculture, in a wider context, also involves gardening, horticulture and livestock raising. All these things include agricultural land management and are thus multifaceted. [17].

The principal capital in improving people's welfare is agricultural land. It includes dry fields, rice fields, plantations, production and protected forests, grasslands, and Imperata grasslands including land for animal husbandry and fisheries. Related to the form of spatial 
land use distribution, there are several theories regarding the form of spatial distribution [18]. Those theories mentioned at least three forms of spatial use of residential land, especially in rural areas.

\subsection{Land Conversion}

Agricultural land conversion is unavoidable as a consequence of economic development. The rate and determinants of agricultural land conversion varies in terms of both spatial and temporal aspects. In common, agricultural lands to be converted are not merely sown with food crops, but also with estate crops, and fishery. Study on agricultural land conversion is somewhat interesting because the determinants of agricultural land conversion stems from many factors including economic, social, and cultural factors [19].

The transition of land functions is generally correlated with the regional development process. The conversion of land may also be said to be a result of regional growth. Most shifts in land use reflect a land tenure imbalance, which is more regulated by the capitalist by the pocketing of construction permits granted by the government.

Paddy fields are empirically agricultural land which is most prone to change of purpose. This is activated by: (1) the population density is usually much higher in rural areas with a dominant paddy agroecosystem than that of dry land agroecosystems, so that the population pressure on land is also higher; (2) many paddy areas are located close to urban areas; (3) the infrastructure of rice fields is generally better than in dryland areas because of the trend of growth in the past; And (4) infrastructure development and settlement facilities, industrial estates, etc. tend to be rapid in flat topographical areas where paddy fields are the dominant agricultural ecosystem in areas with such topography (especially in Java). [20]. Land conversion is a result of economic growth and population growth that continues to increase. This is reflected in (1) growth in natural resource utilization activities due to increasing demand for land use, (2) a shift in the contribution of primary development sectors, particularly from agriculture and resource processing to the secondary sector (manufacturing) and tertiary sector (service). In the law of market economics, land-use change takes place from activities with low land rent to activities with high land rent. What is meant by land rent is the net profit value from land-use activities per unit of land area at a specific time [21].

In fact, different policies have been established related to the issue of control over the operation of paddy fields. There are at least ten regulations/laws concerning the control of this paddy field feature. The implementation, however, has not been realized optimally until now. The lack of data support and the lack of appropriate constructive attitudes to monitor the operation of the paddy fields are partly due to this. There were at least three fundamental obstacles which became the reason why the regulation of land use control was difficult to implement [20]:

1. Policy Alignment Limitations. The government is seeking to ban land conversion, on the one hand. However on the other hand, it facilitates land conversion through industrial / manufacturing development policies and other non-agricultural sectors that actually use agricultural land.

2. Constraints on Policy Implementation. The new land-use control regulations state the provisions imposed on companies or legal entities that will use the land and/or will convert agricultural land to non-agriculture. Therefore, changes in land use to nonagricultural land carried out individually have not been touched by these regulations, where changes in land carried out individually are expected to be very extensive.

3. Planning Consistency Constraints. The Regional Spatial Plan (RSP), which is then continued with the mechanism for granting location permits, is the main instrument in control to prevent the conversion of technical irrigated paddy fields. But in reality, many RSP planned to change the function of technical irrigated paddy fields to non-agriculture 
In connection with the three obstacles above, the ineffectiveness of existing regulations is also influenced by:

a. Weak land administration system;

b. Lack of coordination between related institutions;

c. The mechanism for implementing spatial planning is not yet accessible. Besides, government perceptions of losses due to land-use change tend to be biased downward (underestimate), so the negative impact of land-use change is less considered an issue that needs to be dealt with seriously and consistently.

Furthermore that several laws and regulations over the function of existing agricultural land has various weaknesses. These weaknesses include:

1. The purpose of agricultural land that is protected from the process of transfer of functions is calculated on the basis of the physical condition of the land, although it is reasonably easy to engineer the physical condition of the land so that land use can be carried out without violating the relevant regulations.

2. Existing regulations tend to be appealing and do not have clear sanctions, both regarding the dimensions and the parties to which the sanctions are imposed.

3. If there is a shift in the function of agricultural land that does not comply with the regulations in place, it would be difficult to determine which party is most responsible, keeping in mind that the land conversion permit is a joint decision taken by different agencies.

4. The laws and regulations that apply are sometimes paradoxical and dualistic in nature. On the one hand, it intends to protect the conversion of paddy fields, but on the other hand, the government tends to encourage the growth of industries that incidentally require land. In areas with limited dry land, such as the north coast of Java, this policy will clearly suppress the existence of existing paddy fields.

Two other strategic factors have been left behind. First, there has not been much active involvement of farmers as landowners and actors in local institutions in various efforts to control the conversion of agricultural land functions. Second, commitment has not been built, improvement of the coordination system, and the development of competencies of formal institutions in handling the conversion of agricultural land functions. Finally, these conditions cause the policy instrument for the control of the conversion of agricultural land that has been prepared so far, cannot directly touch the critical nodes of empirical problems that occur in the field.

\subsection{Land Use}

In addition to being a food crop producer, which is rice in this case, rice fields also have several functions. Such roles include preserving food security, providing jobs, safeguarding cultural preservation, and providing a rural environment. Moreover, rice fields also deliver environmental benefits, such as flood and erosion prevention, water recycling, and organic waste. Rice fields also have negative environmental-related values, in addition to positive values. The negative value in question is that rice fields contain methane gas, which is one of the contributors to greenhouse gases.

The land is a unity of different land resources, according to Notohadipawiro, that interact to form a structural and functional system. The type of dominant resource and the strength of interactions that take place between resources decide the existence and behavior of land. Land resources can undergo changes due to human activity [21].

In order to satisfy their needs, both material and spiritual, land use is any sort of human intervention on land. It is possible to group land use into two groups [21]:

1. Agricultural land use

2. Non-agricultural land use. 


\subsection{Protection of Sustainable Agriculture Land}

Law No. 41/2009 on the Protection of Sustainable Food Agricultural Land describes that what Sustainable Food Agricultural Land means is a region of agricultural land which is intended to be preserved and produced in a consistent manner with a view to producing staple foodstuffs for independence, national security and food sovereignty. At the same time, the protection of sustainable food agriculture land itself is identified as a system and process for the sustainable planning, establishment, development, use, promotion, control and supervision of food agriculture land and its territory.

A requirement for national food security is the availability of sustainable agricultural land resources. There are many things closely linked to the availability of agricultural land for food [21]:

1. Potential agricultural food resource land

2. Land productivity

3. Fragmentation of agricultural land

4. The scale of agricultural land tenure

5. Irrigation system

6. agricultural land rent

7. Conversion

8. Farmers' income

9. Agricultural HR Capacity

10. Policy in agriculture

Appointment as permanent agricultural land is one of the policy options considered by some as the most appropriate to prevent the process of conversion of agricultural land. Basically, enduring agricultural land is the designation of an area as a conservation area, or protection, specifically for agricultural businesses. Transfer of agricultural land functions to non-agricultural use is prohibited by a statutory provision. If it can be carried out effectively, then surely land conversion in the conservation area will not occur. Theoretically, assuming it to be effective, this policy option is the most effective way to prevent the conversion of agricultural land [22].

According to the Law of the Republic of Indonesia No 41 of the Year 2009 on the Protection of Sustainable Agricultural Food Lands, the goal is to protect sustainable agricultural property.

1. Protecting food agriculture land and land in a sustainable manner

2. Guarantee the availability of agricultural land for food in a sustainable manner

3. Achieve food independence, resilience and sovereignty

4. Secure the ownership of farmland belonging to farmers

5. Increasing the prosperity and welfare of farmers and the community

6. Increase farmer protection and empowerment

7. 7) Increasing the availability of work for decent lives

8. Ecological equilibrium maintenance

9. Revitalizing agricultural land

Law No. 41/2009 regulates that land that has been designated as sustainable food agricultural land is protected and prohibited from being converted. Protected agricultural land can only be converted for public use, the implementation of which is regulated by statutory regulations. The land conversion that has been determined is done with the following conditions:

1. A strategic feasibility study was conducted

2. Planned land conversion

3. Release of ownership rights from the owner

4. Provided replacement land from land that is converted. 


\subsection{Housing and Settlements}

One of the basic human needs is accommodation and settlement. In order to improve human integrity and efficiency, as well as the quality of a prosperous life in a just and prosperous society, these are crucial factors. Housing and settlements are also part of national growth, which needs to be strengthened and built in an integrated, targeted, planned and sustainable way. [23].

Housing is a community of houses that functions as a residential environment with environmental infrastructure and facilities designed to render the environment a good clean, harmonious and orderly environment and to function as planned. Whereas settlements are part of the community outside protected areas under Law Number 4 of 1992, both in the form of urban and rural areas acting as residential or residential environments and places of operation supporting livelihoods and livelihoods, as provided for in Law No. 1 of 2011 on Housing and Settlement Areas, including housing and public services, infrastructure, etc.

Settlement can also be characterized as an area dominated by a residential environment with a primary position as a residence equipped with environmental infrastructure and facilities and workplaces providing services and employment opportunities to promote livelihoods and livelihoods so that housing functions can be effective and productive.

\subsection{Land Transfer}

Agricultural Land According to the Joint Instruction of the Minister of Home Affairs and Regional Autonomy with the Minister of Agrarian on January 5, 1961, No. Sekra 9/1/12 regarding Understanding of Agricultural Land: "The agricultural land is also all plantation land, fishponds for ponds, livestock grazing land, ex-shrub land and forests which are the livelihoods of the entitled. In general, agricultural land is all land that belongs to people, besides land for housing and business. If on a parcel of land stands the house where someone lives, then the local opinion is what determines how much area is considered home page and how much is agricultural land. "

According to Iqbal and Sumaryanto (2007) [20], empirically, the most vulnerable agricultural land to the conversion function is the rice fields. In rural areas with a dominant paddy agroecosystem, population density is usually much higher than dryland agroecosystems, paddy areas are situated close to urban areas, paddy area infrastructure is generally better than dryland areas, and infrastructure growth and settlement facilities, industrial areas, and so on tend to occur rapidly in flat topographical areas.

Land Transfer Requirements

Transfer of function of Sustainable Agricultural Land as referred to in the Government Regulation No. 1 of 2011 Article 35 Paragraph (2) Letter a can only be done with the following requirements:

1) Having a strategic feasibility study

2) Having a plan for land conversion

3) Exemption of ownership of land rights

4) Availability of substitute land for sustainable food

Strategic feasibility study, as referred to in PP No 1 of 2011 Article 39 Letter a, at least covers a) area and location to be converted, b) potential yield loss, c) risk of investment loss, d) economic, environmental, social impact and culture.

\subsection{Theoretical Frameworks}

Many theories have been put forward by legal and social experts in environmental studies. This study aims to understand, identify, and analyze the flow of facts regarding law 
enforcement on the conversion of sustainable food agricultural land to non-agricultural land. So some of the theories below are used as relevant theoretical frameworks to understand the research being carried out. The theories are:

\subsubsection{Sustainable Development Theory}

The temporary development is currently rife. With the demands of globalization, Indonesia follows the development of the times without seeing future prospects. The development of a society that is instant and origin, the consumptive culture has become ingrained in most Indonesian people. In fact, the essence of development is sustainable development that is not partial, instant, and skin development.

The existence of the concept of Sustainable Development will try to provide a new discourse about the importance of preserving the natural environment for the future, future generations. "Development that meets the needs of the present without compromising the ability of future generations to meet their own needs" [24].

Sustainable development aims to enhance society's well-being, to meet human needs and aspirations. The objective of sustainable development is to strive for an equitable distribution of growth between generations now and in the future. According to the Ministry of Environment, sustainable development (which is more economically oriented) can be measured on the basis of three criteria i.e. [24]:

(1) The use of natural resources or the depletion of natural resources does not result in any waste.

(2) No pollution and other impacts on the environment are present.

(3) Its activities must be capable of increasing utilizable resources or of increasing substitutable resources.

The goal of sustainable development requires efforts to realize it.:

a. Equitable distribution for the benefits of intergenerational development outcomes (intergeneration equity) infers to the use of natural resources for the sake of growth needs to pay attention to reasonable limits in the control of ecosystems or environmental systems and is directed at natural resources that are replaceable and emphasizes the lowest possible exploitation of natural resources unreplaceable.

b. Safeguarding the protection of natural resources and the existing environment and preventing ecosystem disruptions from happening in order to ensure the quality of life of future generations.

c. The utilization and management of natural resources is purely for the sake of pursuing economic development in order to ensure that sustainable use of natural resources is spread equitably between generations..

d. Maintaining people's (community) sustainable wellbeing, both now and in the future (intertemporal).

e. Maintaining the advantages of natural resources and environmental growth or management for long-term or sustainable benefit impacts across generations.

f. Maintaining the quality of human life in line with its habitat between generations [25].

\subsubsection{Welfare State Theory}

This material law is also known as the Welfare State. In the legal perspective, Wilhelm Lunstedt argued:

"Law is nothing but the very life of mankind in organized groups and the condition which makes possible peaceful co-existence of masses of individuals and social groups and the corporation for other ends than more existence and propagation" [25]. 
In this understanding, Wilhelm Lunstedt seems to illustrate that to achieve Social Welfare, the first thing to know is what drives people who live at a certain level of civilization to achieve their goals. Wilhelm Lunsteds' opinion on social welfare is almost the same as Roscou Pound's opinion. However, he wants to emphasize that factually the desire of most people, namely to live and develop it properly.

Seeing the view of social welfare, it can be concluded that the social welfare field includes a general enthusiasm to try with security guarantees so that it can be proven that law order must be based on a scale of certain values, which are not formulated with absolute formulas but by paying attention to the interests of the people that change with changing times, circumstances, and changes in national belief.

The welfare state, according to Sentanoe Kertonegoro, has a risk group that must get attention to be overcome. The reason is that the fundamental risk is collective macro-nature and is felt by the whole or the majority of the community as well as an economic risk. Meanwhile, special risks are more macro-individual, so the impact is felt by individuals or business units [26].

In essence, therefore the welfare state can be defined as an effect of human interests that want to ensure that protection, peace, and well-being do not collapse into misery. The explanation can be described as a driving force, as well as an objective for humans to always search for different ways of achieving prosperity in their lives. So when the desire in a nation's constitution has been assured, then the desire must be guaranteed, and that desire must be realized by the state. The state, in this sense, is the welfare state.

\section{Research Methods}

This research is socio-legal research in the form of empirical research onto the discovery of theories about the process of occurrence and the working of law in society or investigating the relevance of law with other social phenomena. The type of data in this study is primary and secondary data. Primary data were from parties involved as the object of research or from field research. It was necessary to observe the implementation of the regulations on the conversion of sustainable agricultural land. Primary data were taken from interviewing related respondents in the Special Region of Yogyakarta. Meanwhile, the secondary data consisted of Primary Legal Materials, Secondary Legal Materials, and Tertiary Legal Materials

The study was conducted in the Special Region of Yogyakarta by taking samples in Sleman Regency, Bantul Regency, and Yogyakarta City. The data were analyzed using the flow model of analysis [27].

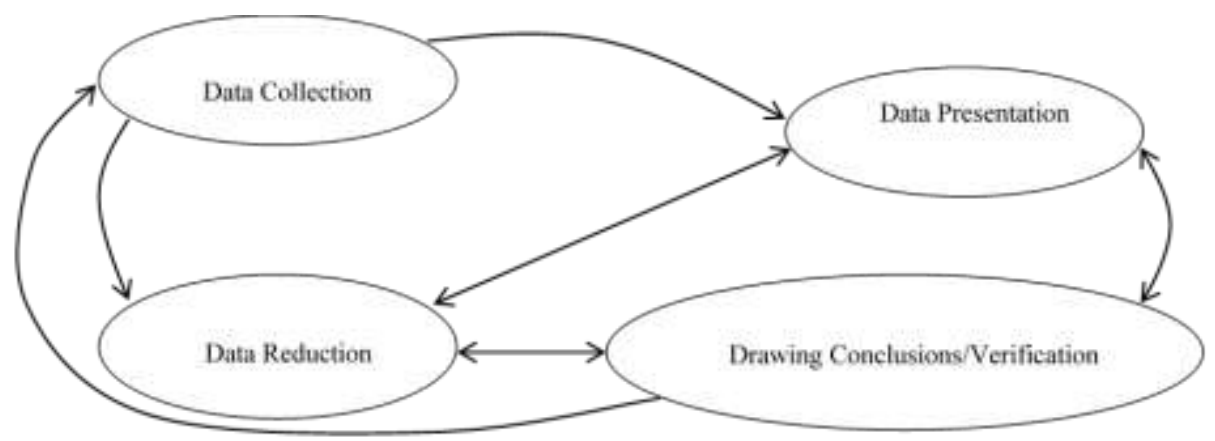

Fig. 1. Flow model of analysis 
In more detail, the data from both library research and field research were processed and analyzed critically and analytically, then presented in a descriptive qualitative manner. The data analysis is a crucial step in the research process.

In connection with the legal research that intends to find answers on legal issues that diverted on the protection for victims, it is crucial to conduct an analysis by not only emphasizing the major premise derived from formal and material law but also sought from existing theories. All of which are directly or indirectly based on data through studies with induced logic.

\section{Result and Discussion}

\subsection{Implementation of Regulations Regarding the Agricultural Land Transfer for Housing in the Special Region of Yogyakarta}

Agricultural land transfer is a threat to the fulfilment of food security and sovereignty. The implication is grave, especially on food production, physical environment, and the level of welfare of rural farmers whose lives depend on their land. This phenomenon is not matched by integrated efforts to develop agricultural land through the designation of potentially new agricultural land [28].

Yogyakarta Special Region Agriculture Office (DIY) said that the conversion of productive agricultural land in DIY reaches more than 250 hectares per year. It has become an obstacle in increasing agricultural output because of diminishing land. As a result, various efforts to reduce land conversion have been made. In fact, a Regional Regulation related to the transfer of land functions has been made. Despite that, the land transfer still occurs since the permit to change the function of agricultural land is the authority of the respective Regency Governments.

Head of the DIY Agriculture Office, Sasongko said, there are many functions of agricultural land in Sleman and Bantul Regencies. On average, this land was converted to build housing, shop houses, and other facilities outside agriculture [29]. The significant depreciation of agricultural land makes the Sleman Regency government move quickly. It was handled by the Department of Agriculture, Food, and Fisheries of Sleman by implementing a number of policies [3]. Ironically, even the amount of land conversion in Yogyakarta Province is already tremendous amidst the limited available land. Every year, changes in land use in the province cover an area of 200 hectares. One of the reasons is the absence of Provincial Spatial Planning (RTRW) and Detailed Spatial Planning (RDTR) in the regencies/municipalities in the Special Region of Yogyakarta (DIY). Therefore, in order to limit the land that has changed its function from agriculture to industry or housing, the Regional Office of the ATR/BPN DIY will urge the speed of completion of the Provincial and Regency/City RTRW review, as well as the completion of the RDTR preparation [30].

The area of agricultural land in Sleman Regency, DI Yogyakarta, is reduced by more than 100 hectares per year. Even though this has not yet impacted the supply of food, this condition has undoubtedly led to reduced rice production every year. At present, the average productivity of rice plants in Sleman Regency reaches 6.2 tons of dry milled grain (GKG) per hectare. With the depreciation of agricultural land more than 100 hectares per year, every year, the decline in grain production reaches 6,200 tons of MPD. According to him, the reduction in the area of agricultural land is due to a large number of land conversion from the previous agricultural land to residential areas, malls, and shophouses. "Transferring is relatively easy to do because most farmlands owned by farmers are not certified," Sleman Regency Government has also sought to maintain and maintain the existence of agricultural land by establishing a sustainable food agriculture land (LP2B) in Sleman Regency covering 
an area of 12,200 hectares. The LP2B area has been stipulated in Sleman Regency Regional Regulation (Perda) No. 12 of 2012 concerning Sleman Regency Spatial and Spatial Planning (RTRW), 2011-2031. Even though it has been determined, Azis said, the Sleman Regency Government is currently still discussing the form of compensation to be given to farmers who own the land.

Table 1. Extensive Use of Agricultural and Non-Agricultural Land in D.I. Yogyakarta [2]

\begin{tabular}{|l|r|r|r|}
\hline \multicolumn{1}{|c|}{ Land Use } & \multicolumn{3}{c|}{$\begin{array}{c}\text { Total Area of Agricultural and Non-Agricultural } \\
\text { Land on D.I. Yogyakarta (Hectares) }\end{array}$} \\
\hline & $\mathbf{2 0 1 4}$ & \multicolumn{1}{|c|}{$\mathbf{2 0 1 5}$} & \multicolumn{1}{c|}{$\mathbf{2 0 1 6}$} \\
\hline A. Agricultural Land & 242,938 & 242,246 & 241,113 \\
\hline A.1. Rice Fields & 55,650 & 55,425 & 55,292 \\
\hline 1. with irrigation & 46,300 & 45,976 & 45,880 \\
\hline 2. rain-fed & 9,350 & 9,449 & 9,412 \\
\hline 3. others & - & - & - \\
\hline A.2. Non-fields & 187,288 & 186,821 & 185,821 \\
\hline 1.Gardens & 104,555 & 103,786 & 103,697 \\
\hline 2. Farms & - & - & - \\
\hline 3. Incultivated land & 921 & 888 & 885 \\
\hline $\begin{array}{l}\text { 4. Others (Ponds, Pools, National } \\
\text { Forest, etc.) }\end{array}$ & 81,813 & 82,147 & 81,239 \\
\hline $\begin{array}{l}\text { B. Non-Agricultural Land residential } \\
\text { roads, offices, etc.) }\end{array}$ & 75,642 & 76334 & 77,467 \\
\hline Total & 318,580 & 318,580 & 318,580 \\
\hline
\end{tabular}

Agricultural land is getting smaller, but in the midst of the lure of investors and the hectic land transfers without permits, local governments are unlikely to force farmers to maintain their agricultural land without providing any compensation. This concerns people's needs and other economic problems.

The land transfer does not only occur in the Sleman Regency but also in a number of regions in DIY, including the City of Yogyakarta, and Kulonprogo area around the new airport. Such rapid development did not have a positive impact on the environment and the welfare of the surrounding community.

The policy on land conversion is expected to be able to accommodate development activities and locations in accordance with its purpose by minimizing conflicts of interest.

What are the sanctions for the violation? Ir Rin Andrijani MT, Head of the Department of Land Management and Supervision and Spatial Planning, said that in 2018 supervision and observation of three illegal buildings had been carried out. The three building owners were given a warning letter up to three times and then submitted the letter to Satpol PP. Yet, when the authors conducted research into the Satpol PP, according to Pambudi Pramudita, SH. MH Head of Section for Enforcement in the Field of Enforcement of Laws and Regulations of Satpol PP, no cases of violations of the illegal buildings that were converted from agricultural land. It means that there is an a synchronization in the three cases. The author's analysis of the perpetrators has fulfilled the requirements, so no further legal action was taken.

There are office buildings that convert agricultural land, but they are allowed for some reasons. This was said by Agus Puguh Santoso, the Head of the Data and Information Section, who informed that the BMKG climatology station office located in Sinduadi Regency Sleman Road is built on fertile land which was previously rice fields. However, building permits are still released with the reason that the construction of the climatology station must be far from tall buildings and may not be in a residential area. 
Table 2. Land Transfer According to Land and Spatial Data [31]

\begin{tabular}{|r|r|}
\hline Years & Area (Hectares) \\
\hline 2011 & 222.41 \\
\hline 2012 & 180.19 \\
\hline 2013 & 82.85 \\
\hline 2014 & 57.86 \\
\hline 2015 & 79.32 \\
\hline 2016 & 92.87 \\
\hline 2017 & 141.52 \\
\hline 2018 & 163.72 \\
\hline
\end{tabular}

Sleman Regency is a critical food-producing area in DIY with a total area of 21,907 ha of paddy fields contributing $40 \%$ of all paddy fields in DIY. While on the other hand, the conversion of agricultural land in the region of Sleman Regency occurs very massive for various uses such as settlements, housing, apartments, hotels, industrial areas, and services as well as other non-agricultural uses. Bantul and Kulonprogo regions also experience a phenomenon similar to conditions that occur in Sleman 51. Economic factors are one of the causes of the conversion of agricultural land to non-agricultural land, as previously explained. This encourages the owners of agricultural land, especially rice fields, to sell their land because they are forced to live. The lure of high land selling prices will also be a strong attraction of land brokers52.

Regarding the duties and responsibilities of the state towards its citizens, according to Frans Magnis Suseno, the state is essentially tasked with striving for the general welfare. For this reason, the state must strive for all the prerequisites, conditions, and infrastructure so that the community can live in justice and prosperity [32]. This is consistent with Mac Iver that the task of the state has three main functions, namely: 1. order; 2. protection and 3. maintenance and development.

Characteristics of modern law nation or welfare state are [33]:

a. The state style is the "welfare state," or the state that prioritizes the interests of the people.

b. The state intervenes in all fields of public life.

c. The liberal economy has been replaced by an economic system led by the central government.

d. The task of the welfare state is to organize public interest.

e. The state has to maintain security in the broadest sense, in all parts of people's lives.

Indonesia is a state of the law explicitly regulated in 1945 Constitution Article 1 Paragraph (3). Also, according to Syahran Basah, Indonesia is a law state of Pancasila [34].

\subsection{Law Enforcement against Violation of the Use of Agricultural Land for Housing in Special Region of Yogyakarta}

The points of law enforcement lie in the factors that might influence it. Soerjono Soekanto mentioned 5 (five) factors of legal effectiveness: [4]

1) The legal factor itself, in this theory, is limited to laws and regulations;

2) Factors of law enforcement, those shaping the law and enforcing it;

3) Considerations related to facilities that facilitate law enforcement;

4) Factors of the Society, the setting in which the law applies or applies;

5) Cultural factors based on human initiative in the societies regarding job, development and taste

Lawrance M. Friedman claims that three aspects of the legal system, namely the legal framework, the content of the law and the legal culture, do not rely on efficient and active 
law enforcement. The legal system applies to law enforcement officers, the law protects the legal content, and the legal community is a living law accepted in a society [4].

Law enforcement is carried out when there is a violation of the existing legal rules, so it cannot be done haphazardly. Regarding the transfer of function of agricultural land for housing and housing, it is very strict to be carried out, especially for areas where land is increasingly shrinking.

Licensing is an activity for fostering, regulating, controlling, and supervising spatial use activities. Space Utilization Permit and location permit are permits required in spatial use activities in accordance with statutory provisions. The permit needs to get permission from the regent or appointed official. The use of this space is made to ensure that the land is used according to spatial planning, zoning regulations, and minimum service standards in spatial planning, and the most important is the public interest. The community can be protected if there are impacts.

Law number 41 of 2009 concerning Protection of Sustainable Agricultural Land has stipulated sanctions for violations of the conversion of agricultural land.

Article 46 Law number 41 of 2009 :

(1) Individuals who transfer the Sustainable Agriculture Land, as referred to in Article 23 paragraph (2) shall be sentenced to a maximum imprisonment of 5 (five) years and a maximum fine of IDR 1,000,000,000 (one billion rupiahs) according to the provisions in Article 72 of Law Number 41 Year 2009 concerning Protection of Sustainable Agriculture Land.

(2) In the case of acts as referred to in paragraph (1) committed by government officials and/or regional government and/or district government, the sentence is added 1/3 (one third) of the penalties.

Article 47

Every government official and/or regional government and/or district government who has the authority to issue licenses for the conversion of Sustainable Agricultural Land does not comply with the provisions referred to in Article 23 paragraph (2) shall be sentenced to a minimum of 1 (one) year imprisonment and a maximum of 5 years (five) years and / or a fine of at least IDR 1,000,000,000.00 (one billion rupiahs) and a maximum of IDR 5,000,000,000.00 (five billion rupiahs) according to the provisions in Article 73 of Law Number 41 Year 2009 concerning Protection of Sustainable Agricultural Land.

Article 48

(1) In the case of a criminal offense as referred to in Article 46 paragraph (1) carried out by a legal entity, company or corporation, the management shall be sentenced to a maximum imprisonment of 2 (two) years and a maximum of 7 (seven) years and a minimum fine of IDR 2,000,000,000.00 (two billion rupiahs) and a maximum of IDR 7,000,000,000.00 (seven billion rupiahs) in accordance with the provisions in Article 74 paragraph (1) of Law Number 41 Year 2009 concerning Protection of Sustainable Food Agricultural Land

(2) In addition to criminal fines, as referred to in paragraph (1), legal entities, corporate companies may be subject to criminal offenses in the form of a. confiscation of assets resulting from criminal acts, b. cancellation of employment contracts with the government, c. dismissal of management, and/or d. prohibition on the management to establish a legal entity, corporation in the same line of business.

(3) In the event that the acts as regulated in this chapter result in losses, the criminal sanctions imposed may be added to the payment of damages.

Transferring the function of agricultural land to settlements or offices requires the right solution to achieve justice by prioritizing the common interests of increasing food production and increasing the economic sector of the agricultural sector. The protection of farmers and their farming businesses is still needed in the form of laws or government regulations so that farmers have economic incentives to work in the agricultural sector. National development 
policy must aim at realizing the conditions of a resilient agricultural sector, not tending to pursue high economic growth, especially districts/cities that have regional autonomy authority. The role of local government and the community needs to be improved in spatial planning to utilize land in accordance with its purpose so that social functions in achieving aspects of justice can be fulfilled

Law enforcement also cannot be maximized because the Government of the Special Region of Yogyakarta does not yet have sufficient regulations to control the conversion of agricultural land into settlements, including the construction of hotels and apartments. "Even though the RTRW (regional regulation on spatial planning) cannot be done," said Head of Spatial Planning, Public Works, Housing, Energy, and Mineral Resources Department DIY Hananto Hadi Purnomo, Friday, March 27, 2015.59

\subsection{The Ideal Concept of Law Enforcement So That Agricultural Land Conversion Does Not Occur}

Reviewing the above analysis, law enforcement on the conversion of agricultural land is currently lacking. If this is not stopped immediately it will repeat itself all the time. In this case, the losers are farmers. Whereas according to the theory of the welfare state law, the state's obligation is to provide welfare for all citizens, including land owners.

In the future, to overcome the conversion of agricultural land to non-agricultural functions, it will be done in a preventive and repressive manner. Currently it has been done, but from the results of research, land conversion is still happening.

Referring to the diagram of the thematic presentation of agricultural land conversion and food security below, in the future, in enforcing law, it is necessary to classify the causes of land conversion.

There is a change in the function of agricultural land due to several things including population growth, urban expansion, so this is for the public interest. But there are also those for business purposes or to increase their finances.

Reviewing the diagram above, in the future, in carrying out law enforcement, it is ideal to see what land conversion is for what purpose, so that the sanctions imposed will be seen for what purposes the land conversion is carried out. After all, the ultimate goal of good law enforcement is for the welfare of the entire community. 


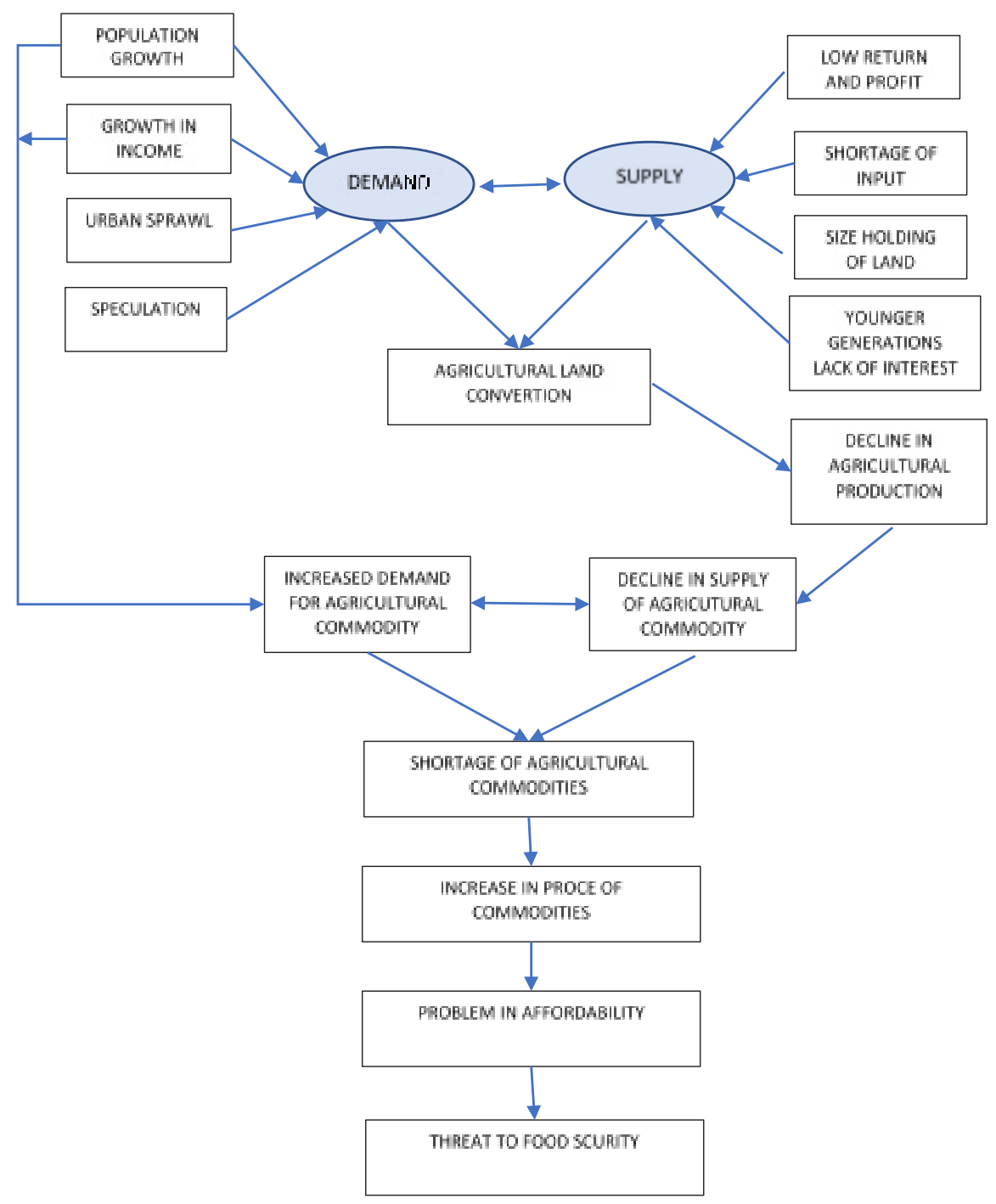

Fig. 1. Diagram Thematic presentation of agricultural land conversion and food security [1]

\section{Conclusion}

The implementation of these regulations has, in principle, all been applied both to the requirements for the conversion of agricultural land, permits, and spatial use, however illegal building occupants still occur. The Sleman local government has even implemented a moratorium on agricultural land used for hotel construction. The hotel or residential building that stands today is licensed before the moratorium is implemented.

Law enforcement against violations of the use of Sustainable Agricultural Land that is used for offices and housing in DIY has not been carried out optimally. Although administratively, there have been some actions, the law has never been fully implemented. 
Throughout the research, there has never been a violator of the conversion of agricultural land for housing or offices that were imposed with criminal sanctions. Both Sleman and Bantul districts prioritize preventive action by conducting raids or operations in the field. If some parties are suspected of violating, the warning notice will be carried out up to three times. Then if until the third notice is not met, legal proceedings will be continued by Civil Service Police Unit.

In the future, it is necessary to improve law enforcement so that land conversion is reduced. In addition, in enforcing the law, it is necessary to consider what purpose the land use change is being used.

\section{References}

1. P. K. Govindaprasad and K. Manikandan, Int. Res. J. Agric. Rural Dev. 3, 1 (2014).

2. Badan Pusat Statistik, No Title (Yogyakarta, 2017).

3. S. Widya, Tribunnewsjogja (2019).

4. B. Burdatun, J. IUS Kaji. Huk. Dan Keadilan 4, 452 (2016).

5. I. Y. Isdiyanto, J. Media Huk. 26, (2019).

6. Y. Suhardin, Mimb. Huk. 21, (2009).

7. F. Jaramillo, R. Nixon, and D. Sams, Policing 28, 321 (2005).

8. S. Rahardjo, Penegakan Hukum Suatu Tinjauan Sosiologis (Genta Publishing, Yogyakarta, 2009).

9. S. Mertokusumo, Mengenal Hukum (Liberty, Yogyakarta, 1999).

10. H. Arianto, Lex Jurnalica 7, 115 (2010).

11. Mardjono Reksodiputro, Sistem Peradilan Pidana Indonesia, MelihatKejahatan Dan Penegakan Hukum Dalam Batas-Batas Toleransi (Pusat Keadilan dan Pengabdian Hukum, Jakarta, 1994).

12. M. N. Islami, Hukum Dan Kebebasan Berpikir (Pustaka Pelajar, Yogyakarta, 2015).

13. M. Erwin, Hukum Lingkungan Dalam Sistem Perlindungan Dan Pengelolaan Lingkungan Hidup Di Indonesia (Refika Aditama, Bandung, 2015).

14. J. L. Ferguson and L. Granier, Am. Bar Assoc. Nat. Resour. Environ. 30, (2015).

15. D. Riskanita, Judul Kerusakan Lingkungan Sebagai Akibat Alih Fungsi Lahan Perbukitan Menjadi Lahan Perkebunan Di Kabupaten Ponorogo (Studi Kebijakan Formulasi Hukum), Universitas Muhammadiyah Yogyakarta, n.d.

16. A. Puspasari, (2012).

17. W. H. Verheye, (n.d.).

18. R. Bintarto, Pengantar Geografi Kota (Spring, Yogyakarta, 1977).

19. J. Mariyono, J. Ekon. Stud. Pembang. 7, (2006).

20. M. Iqbal and Sumaryanto, Strateg. Pengendali. Alih Fungsi Lahan Pertan. Bertumpu Pada Partisipasi Masy. 5, 167 (2016).

21. M. A. W. Handari, Implementasi Kebijakan Perlindungan Lahan Pertanian Pangan Berkelanjutan Di Kabupaten Magelang, Universitas Diponegoro, 2012.

22. P. Simatupang and B. Irawan, in Multifungsi Dan Konversi Lahan Pertan. (Bogor, 2003).

23. A. Hariyanto, J. Perenc. Wil. Dan Kota UNISBA 7, pp. 11 (2007).

24. E. Salim, Askar Jaya (2004).

25. A. . Rahardian, Strategi Pembangunan Berkelanjutan (2016).

26. S. Kertonegoro, Jaminan Sosial Dan Pelaksanaannya Di Indonesia. (Mutiara Sumber Widya, Jakarta, 1987).

27. M. B. Miles and A. M. Huberman, Analisis Data Kualitatif (UI Press, Jakarta, 1992).

28. R. B. Prihatin, J. Aspir. 6, 105 (2016).

29. S. D. Setiawan and F. Yolanda, Republika 13 March 2, (2019). 
30. Tirto (2016).

31. Dinas Pertanahan dan Tata Ruang kabupaten Sleman, No Title (n.d.).

32. F. M. Suseno, Etika Politik, Prinsip-Prinsip Dasar Kenegaraan Modern (Gramedia, Jakarta, 1991).

33. Bachsan Mustafa, Sistem Hukum Indonesia Terpadu (Citra Aditya Bakti, Bandung, 2003).

34. S. Basah, Eksistensi Dan Tolok Ukur Badan Peradilan Administrasi Di Indonesia (Alumni, Bandung, 1985). 